${ }^{1}$ Ph.D., Dr. Sc., Professor, Department of Electrical Engineering, Acting Dean of the Faculty of Rocket and Space Technology, National Aerospace University, Kharkiv, Ukraine

${ }^{2}$ PhD., Associate Professor, Department of Informatics, Kharkiv National University of Radio Electronics, Kharkiv, Ukraine

\title{
INTELLIGENT SUPPORT OF MULTILEVEL FUNCTIONAL STABILITY OF CONTROL AND NAVIGATION SYSTEMS
}

Relevance. Ensuring functionally steady operation of dynamic objects' movement in the presence of abnormal situations is one of the most prospective research problems in the area of technical diagnostics and restoration of system operability. Use of intelligent control methods and algorithms for solving this scientific and technical task can significantly extend the functionality and improve the performance of control systems.

The aim is the formation of an approach to determine the control effect that ensures the functional stability of the CNS in the presence of abnormal situations.

Method. The concept of ensuring functionally stable control of dynamic objects' movement has been offered. Well-known diagnostic methods and tools have been systematized and on that basis new models and methods for deep diagnosis of the functional state of the control and navigation systems up to the reason of abnormality have been developed. Models and methods for multi-level parrying of the reason of abnormal situations through control over the diagnosis have been synthesized, they use such redundant resources as signal and parametric adjustment, reconfiguration of algorithms and commutation of equipment.

Results. The results of the solution of a number of combined scientific and technical problems aimed at the multilevel ensuring of the functional stability of CNS have been presented.

Conclusion. Analyses of tendencies of theoretical investigation and practical achievements in ensuring functionally steady control of CNS at occurrence of abnormal situations has been carried out. The concept of intelligent support of the functionally steady control of CNS has been developed. The concept is based on the principles of multilevel hierarchical diagnosis of CNS to the parried reason of abnormal situation, as well as on the situational approach to eliminate the consequences of failures in accordance with the level of its application. As a result of analysis and synthesis of known approaches to diagnosing the technical state of dynamic objects, the new models and methods for deep diagnosis of the CNS' functional state have been formed, that makes possible to determine the failure up to the reason of abnormality. Models and methods for multi-level parrying of abnormality through control over the diagnosis with the use of available intelligent on-board resources have been offered. A hardware-software complex for experimental research of theoretical positions have been developed, and conducted experiments have been verified the possibility of extending the functionality of the system to counter abnormal situations. As a result of conducted experiments in real-time scale, diagnosis and restoration of CNS' functional state during a time not exceeding $42.2 \%-48.4 \%$ of the transient time of the system in normal operation mode have been implemented.

Keywords: control, stabilization, orientation, functionally steady movement control, abnormal situation, diagnosis, parrying the reason of abnormality.

\section{NOMENCLATURE}

DLM is a diagnostic logical model;

TLM is a tabular logical model;

CNS is a control and navigation systems;

FDM is a functional diagnostic model;

SFM is a "small" failures model;

HSC is a hardware and software complex;

$\mathrm{PM}$ is a power amplifier;

$\mathrm{AM}$ is a actuating mechanism;

$\tilde{y}(t)$ is a vector of the measured variables of the perturbed movement, $\tilde{y}(t) \in Y^{n}$;

$A(\lambda), B(\lambda)$ is a matrixes of the appropriate dimensionalities characterizing a linearized part of the system;

$\lambda$ is a $\mu$-dimensional vector of the diagnostic parameters of the reasons of abnormal situations;

$$
F[\lambda, u(t)] \text { is a } r \text {-dimensional vector function }
$$
describing essential static nonlinearities of the system;

$u(t)$ is a $r$-dimensional vector of input signals, $u(t) \in U^{r}$

$\Delta y(t)$ is a vector of deviations of the measured variables

(c) Firsov S. N., Pishchukhina O. A., 2018

DOI $10.15588 / 1607-3274-2018-2-20$ of the perturbed movement from the nominal ones $\Delta y(t) \in Y^{n}$;

$R, T$ is a matrixes of the appropriate dimensionalities; $\Delta u(t)$ is a input signals; $\Delta u(t) \in U^{r}$;

$\psi(t)$ is a $m$-dimensional vector of the controlling influences, providing execution of $\Delta y(t) \underset{t \rightarrow t_{k}}{\rightarrow} 0$ for the finite number of iterations $t_{k}$;

$\hat{y}(t)$ is a output of a reference model;

$\Delta \lambda_{i}$ is a direct diagnostic sign $\Delta \lambda_{i}=\lambda_{i}-\lambda_{i H}$;

$\lambda_{i H}$ is a nominal value of a parameter of the abnormal situation;

$G$ is a Luenberger matrix ;

$\frac{\partial[\cdot]}{\partial \lambda_{i}}$ is a partial derivative;

$\frac{D[\cdot]}{\partial \lambda_{i}}$ is a generalized differentiation;

$S_{2}($.$) is a two-digit predicate;$ 
$\delta_{i}$ is a threshold value depending on the accuracy of data representation and the subsequent data processing; $V_{\lambda}(t)$ is a function of sensitivity on the diagnostic parameter $\lambda_{i}$;

$\sigma_{j}$ is a threshold value of a ratio under the sign of a predicate $S_{2}[\cdot]$;

$t_{O}$ is a time point of the abnormal situation affecting the system;

$t_{d e t}$ is a time point of its detection;

$t_{c d}$ is a time point of the completion of diagnosing and determination of parameters of the abnormal situation;

$t_{p c}$ is a time point of the beginning of parrying by signal setup;

$t_{p r}$ is a time point of the beginning of parrying by equipment reconfiguration;

$t_{c p}$ is a time point of completion of the procedure of parrying of an abnormal situation.

\section{INTRODUCTION}

Exploration of natural phenomena like storms, tornados, earthquakes, volcanic eruptions, including effects they cause, are inseparably linked with the practice of application of autonomous dynamic objects. In most cases, the distinguished characteristic of such objects functioning is their remoteness and, very frequently, impossibility of operative elimination of abnormalities in their operation. Those circumstances define the appearance of new specific requirements to operability of both autonomous systems in general and elements ensuring their operation through the whole life cycle at the design , development and operation stages.

Ensuring functionally steady operation of dynamic objects in the presence of abnormal situations is one of the most prospective research problems in the area of technical diagnostics and restoration of system operability. Use of intelligent control methods and algorithms for solving this scientific and technical task can significantly extend the functionality and improve the performance of control systems, which defines the topical object and subject of conducted research. The object of research is the processes of the functioning of control and navigation systems in the presence of abnormal situations. The subject of research is models and methods for ensuring the functional stability of control and navigation systems. The aim of research is the formation of an approach to determine the control effect that ensures the functional stability of the CNS in the presence of abnormal situations.

\section{PROBLEM STATEMENT}

The emergency mode of functioning of a linearized object with essential nonlinearities in a case of the impact of disturbances is described in the Cauchy form by the vector equation of the perturbed movement:

$$
\dot{\tilde{y}}(t)=A(\lambda) \tilde{y}(t)+B(\lambda) F[\lambda, u(t)], \tilde{y}\left(t_{0}\right)=\tilde{y}_{0}
$$

For the description of a deviation of CNS perturbed movement in the abnormal situation (1) from the reference one the following equation is used:

$$
\Delta \dot{y}(t)=R \Delta u(t)+T \psi(t) ; \Delta y\left(t_{0}\right)=\tilde{y}_{0} ; \Delta y(t) \in Y^{n} .
$$

The aim is to define the control action, providing the functional stability of CNS while abnormal situations.

\section{REVIEW OF THE LITERATURE}

Failures and malfunction of elements and units of control systems, as a result of abnormal situations appearance, are the one of the main problem while fulfilling the missions [13]. According to the results of statistical studies, the most vulnerable systems, which are subjects to technical breakages, have been control and navigation systems (CNS), and also its main measuring and actuating subsystems.

Necessity of the solution of the given problem has contributed into increasing the functionality of dynamic objects in terms of their application and efficiency [4-5]. It has fostered the progress in extension of the functional capabilities of CNS for parrying the abnormal situations of different kind, which is implemented by ensuring the functional stability of the most vulnerable subsystems to different breakages, failures and other abnormalities of CNS and their elements. The functional stability is ability of the system, device or units to perform the required functions during the preset time at the presence of abnormal situations [6-7]. It allows overcoming the objective contradiction consisting in need of fault-free mission fulfilling, on the one hand, and existence of limited resources for maintenance of their operability in real time, on the other hand. Using of standard methods and technologies to support operability and stability of similar systems doesn't cover all set of the reasons of abnormal situations origins, and the unreasonable adjusting of redundancies leads to increase in their weight, overall dimensions, energy consumption and other performance indices growth. For effective mission implementation by the autonomous dynamic object, methods of restoration of its functional properties have been offered. The aim of those methods implementation is to ensure the functionally steady operating of CNS throughout the required period in the conditions of counteraction to different destabilizing factors leading to the partial and/or complete loss of operability.

The theoretical research started in the early seventies in the field of the functional stability of CNS now continues for the purpose of creation of perfect design tools for complex technical objects development. At the same time, CNS functional stability ensuring is rather new direction which is at the stage of its formation. O. Mashkov in paper [8] describes the basic reasons of this direction emergence and obvious advantages of functionally stable systems in comparison with unstable ones. A few scientists have made a contribution to the development of the functional stability theory using some kind of intelligent approaches, for example, Ju. Kravchenko offered an actual direction connected with application of hardware redundancy to restore technical objects [9]; P. Castaldi, N. Mimm and S. Simani considered fault-tolerant approach on the base of software and hardware redundancy with regard to nonlinearity of control systems [10]; J. Huang improved the common approach having implemented control reconfigurability through fuzzy logic techniques for sensor placement. According to those groups of researchers and their published papers ensuring the functional stability for CNS allows to reduce the time of system debugging, its 
energy consumption and mass-dimensional characteristics and leads to extension of system life cycle. The major drawback of those scientific ideas and technical solutions is absence of a complex approach to intelligent technical diagnostics before fault's elimination and further flexible system restoration with regard to available onboard resources.

One of perspective ways to support the fault-tolerant operation of CNS is its intelligence consisting in ensuring the system with ability of its self-diagnosis [11-12], and then having got the diagnosis results to recover its operability. The analysis of tendencies of small-size autonomous dynamic objects development shows, that the quality assessment is carried out not only by a criteria of functionality and payload mass, but also on indices of the onboard "intelligence" power. Until recently, CNS of the previous generations were getting improved mostly at the expense of the hardware component, that in the case of the modern tactical-economic requirements and appearance of new, more complex challenges is not sufficient.

Research of some domestic and foreign researchers are devoted to issues of CNS intelligence under conditions of uncertainty. The intelligent automatic control systems steady against failures, designed after appearance of new direction of the theory of automatic control [12-13], have become a result of such development. Results of the research, devoted to the development of CNS tolerant to failures, are provided in the articles [6-8]. In scientific works [4-6] the systems, capable to parry failures in aircraft control systems, and in [8-10] systems, compensating failures in the executive mechanisms, are described. The author of [1213] selects the following necessary and sufficient conditions of ensuring functional stability of CNS: (1) presence of robustness property (no sensitivity while changing of parameters or structures of system); (2) reconfigurability (changing of the CNS parameters and structure for the purpose of compensations of uncontrollable occurred anomalies).

The analysis of tendencies in the field of theoretical researches in ensuring functional stability of CNS promotes identification of the new scientific direction of complex studying of a problem of functional stability and development of approaches to its intelligence on the basis of two independent directions of a research connected with diagnosing and parrying of the reasons of abnormal situations.

\section{MATERIALS AND METHODS}

Functional resistance of CNS to abnormal situations is carried out by fulfillment of the principle of three-level hierarchy. The first level of hierarchy - subsystem. At this level are devices, which are carrying out target functional transformations for CNS, are developed and designed.

To suppress the influence of abnormal situations for an autonomous dynamic object and subsystem communications, the second level of the self-organization hierarchy is formed - system level. At this level the diagnosis of a functional condition of the whole CNS is made, which means detecting the abnormal situation itself, defining a place of the failure and its class, i.e. providing the full diagnosis of the abnormal situation which has caused deterioration in quality of functioning of CNS. Having obtained the diagnosis, the procedure of parrying of the abnormal situation by redundant means of CNS starts.

The third level of self-organization - mega system level. At this level, diagnosing of all the mission or project is carried out in general, if the abnormal situation has not been managed as diagnosed one at the lower levels: subsystem and system. With that, the abnormal situation is localized and classified under available information, as well as its reason and type is defined. On the basis of this diagnosis and the available onboard resources of an autonomous dynamic object, as well as taking into account political, military, economic and strategic factors, the decision about abnormal situation parrying is made on the mega-system.

While using methods of redundancy control, synthesis of algorithms has to be made with use of the diagnostic models applied at the first stage. Thus, the offered concept to support the functional stability provides adaptation, structural and semantic unity of models and, respectively, the algorithms used at all stages of control.

Among a number of approaches to diagnosing of technical systems in the context of the considered concept, the most perspective one is a signal-parametric approach, as it is based on the assumption, that origin of any reason of the abnormal situation $d_{i} \in D_{j}$ represents an uncertain event. Within this approach, special functional diagnostic models (FDM) formalize description of the system, which is necessary for the solution of diagnostic tasks for connecting the direct and not measured signs with indirect and measured ones. In general form, FDM connects a deviation from reference value of object's signal characteristics $(\Delta x(t)$, $\Delta y(t))$ to deviations from rated values of the appropriate target diagnostic signs $\Delta \lambda_{i}$.

For the non-linear system, it is possible to develop several types of FDM. We will provide, for example, a diagnostic model for "small" failures $\left(\Delta \lambda_{i}>>\Delta \lambda_{i}^{2}\right)$, socalled SFM-model:

$$
\begin{gathered}
\Delta \dot{y}(t)=G \Delta y(t)+\frac{\partial A(\lambda)}{\partial \lambda_{i}} \hat{y}(t) \Delta \lambda_{i}+\frac{\partial B(\lambda)}{\partial \lambda_{i}} F\left[\lambda_{H}, u(t)\right] \Delta \lambda_{i}, \\
\Delta y\left(t_{0}\right)=\tilde{y}
\end{gathered}
$$

Connection between direct and indirect diagnostic signs is non-linear (3), and, therefore, for conversion to qualitative models we use different conversions of a sign $\Delta y(t)$ to a numerical sign, and further from an absolute scale of signs to a scale of denomination we apply the two-valued predicate equations:

$$
Z_{j}=S_{2}\left(\eta_{i j}-\delta_{i}\right)= \begin{cases}1, & \eta_{i j} \geq \delta_{i}, \\ 0, & \eta_{i j}<\delta_{i}, j=\overline{1, m} .\end{cases}
$$

Consistently applying (4), we obtain rectangular Boolean tables of $\mu \times m$ size. The number of lines in the table corresponds to number of $\Delta \lambda_{i}$, and the number of columns $-\Delta y(k)$. This table represents a variant of diagnostic logical model (DLM) - tabular logical model (TLM). 
Initial data for development of models and tools of CNS diagnosing are results of a research of a subject to diagnosing, namely: hierarchy of diagnostic models, requirements to diagnosing depth, diagnosing time, reliability of the diagnosis, set of initial signals and requirement to the mode of input signals. The result of the solution of the major tasks is the machine realized algorithms and all process of diagnosing of CNS in the form of the tree-like knowledge base. Joints of a tree contains the corresponding signs, representing the two-digit predicate equations on a set of data array of discrete values of system signals, which are available to measurement:

$$
\mu_{j}=S_{2}\left[\Delta y(t), V_{\lambda}(t), \sigma_{j}\right] .
$$

The equations (5) requires solution on the corresponding data array of discrete values with use of a confidence coefficient, reducing the influence of the destabilizing factors on decision quality. As a result of the solution (5), we receive value 0 or 1 , determining the direction of further moving on a tree. The tree finishes with leaves, which correspond to possible conditions and the set of abnormal situations of CNS.

Application of FDM has allowed to reduce a number of the control points, representing additional measurable outputs of the system.

Parrying of the reasons of abnormal situations is feasible by means of the appropriate redundant resources at the appropriate level of ensuring the functional stability of CNS. The more excess resources are available, the quality of parrying is higher. In practice a set of redundant resources $R$ is limited. The obvious contradiction between the diagnosing depth (which indirect characteristic is the power of a set $D$ ) and flexibility of restoration (indirect quantitative assessment of which is the power of a set $R$ ) can be resolved by finding a compromise.

For the purpose of specificity of the task of multi-level parrying, we will consider restoration of the functional status of CNS. For the solution of this task, CNS should contain redundant resources in its structure, such as: a) supplemental signal entries; b) means of parametric adjustment; c) redundant instruments, units, devices; d) additional algorithms and programs; e) other resources.

For the description of specific of control mentioning described redundancy, we use equation of CNS's movement, perturbed of an abnormal situation (2).

The control input is defined by approaches to ensure stability of dynamic systems. The most effective is the discrete analog of the second Lyapunov's method.

The second Lyapunov's method is a formation of the special extra scalar function named Lyapunov's function $V[\Delta y(k)]$, and further investigation of its properties, and also properties of its first difference, defined on necessary trajectory of equation.

The linear system described by the equation (2) is asymptotically steady, if $\left|\sigma_{i}\right|<1, i=\overline{1, m}$. Also, if in the area $\Omega$ for system (2) there is the definitely positive function $V[\Delta y(k)]$, which first difference $\Delta V[k, k+1]$ is definitely negative, then equilibrium position is asymptotically steady, i.e.

$$
\lim _{k \rightarrow \infty} \Delta y(k)=0 \text {. }
$$

We select the compensating influence $\psi(k)$, coming from a following inequality $\Delta V[k, k+1]<0$ for a finite difference of $\Delta V[k, k+1]$ in the area $\Omega$, i.e. from execution of a condition of definite negativity of the function:

$$
\psi^{T}(k)=-2 \Delta y^{T}(k) R^{T} Q T\left[T^{T} Q T\right]^{-1} .
$$

Free choice of Lyapunov's functions structure allows to obtain different options of restoration of the functional state, different in structure and quality indices of dynamics reflecting compensating of consequences of abnormal situation impact.

Self-organization of CNS is based both on obtaining the complete diagnosis about the functional state after an abnormal situation and on flexible use of the redundant resources allowing to parry the revealed abnormal situation. Thus, high-quality parrying of abnormal situations requires: full diagnosis of functional state of an object of diagnosing, reflecting time of appearance of an abnormal situation, its place, class and specific physical reason; availability of redundant resources, covering a set of compensated abnormal situations; concept of a choice of redundant resources, considering previous abnormal situations proceeding from the current situation and tasks of a mission; methods of effective parrying of an abnormal situation of an object of diagnosing; resources for determination of the technical condition of a restored object of diagnosing.

\section{EXPERIMENTS}

For experimental verification of the offered concept of ensuring the functional stability the appropriate pilot studies on the developed hardware and software complex (HSC) have been conducted. In particular, computer simulation of abnormal situations of functionally steady CNS, being in the modes of stabilizing and orientation of a platform, have been carried out and their influence on a movement deviation from rated one have been investigated using HSC.

On figure 1 the results of experimental research are presented: influence of power amplifier (PA) and actuating mechanism (AM) transmission ratio reduction by $30 \%$ in the mode of stabilizing of angular position of a platform. The dotted line represents graphs of CNS output signals changing in the system without functional stability, and a solid line - in the case of the permanently connected subsystem to ensure the functional stability of CNS.

\section{RESULTS}

Investigated failure occurred in AM and time point of its detection matches time point of parrying through reconfiguration of equipment $\left(t_{d e t}=t_{p r}\right)$. After determination of failure class and failure mode, parrying of a failure through signal setup is carried out $\left(t_{p s}=t_{c d}\right)$. The total time $t_{c p_{1}}$, spent for failure detection, determination of failure and its parrying is:

$t_{c p_{1}}=\left(t_{\mathrm{det}}-t_{o}\right)+\left(t_{c d}-t_{\mathrm{det}}\right)+\left(t_{c p}-t_{p s}\right)=t_{c p}-t_{o}=1.42 c$. 


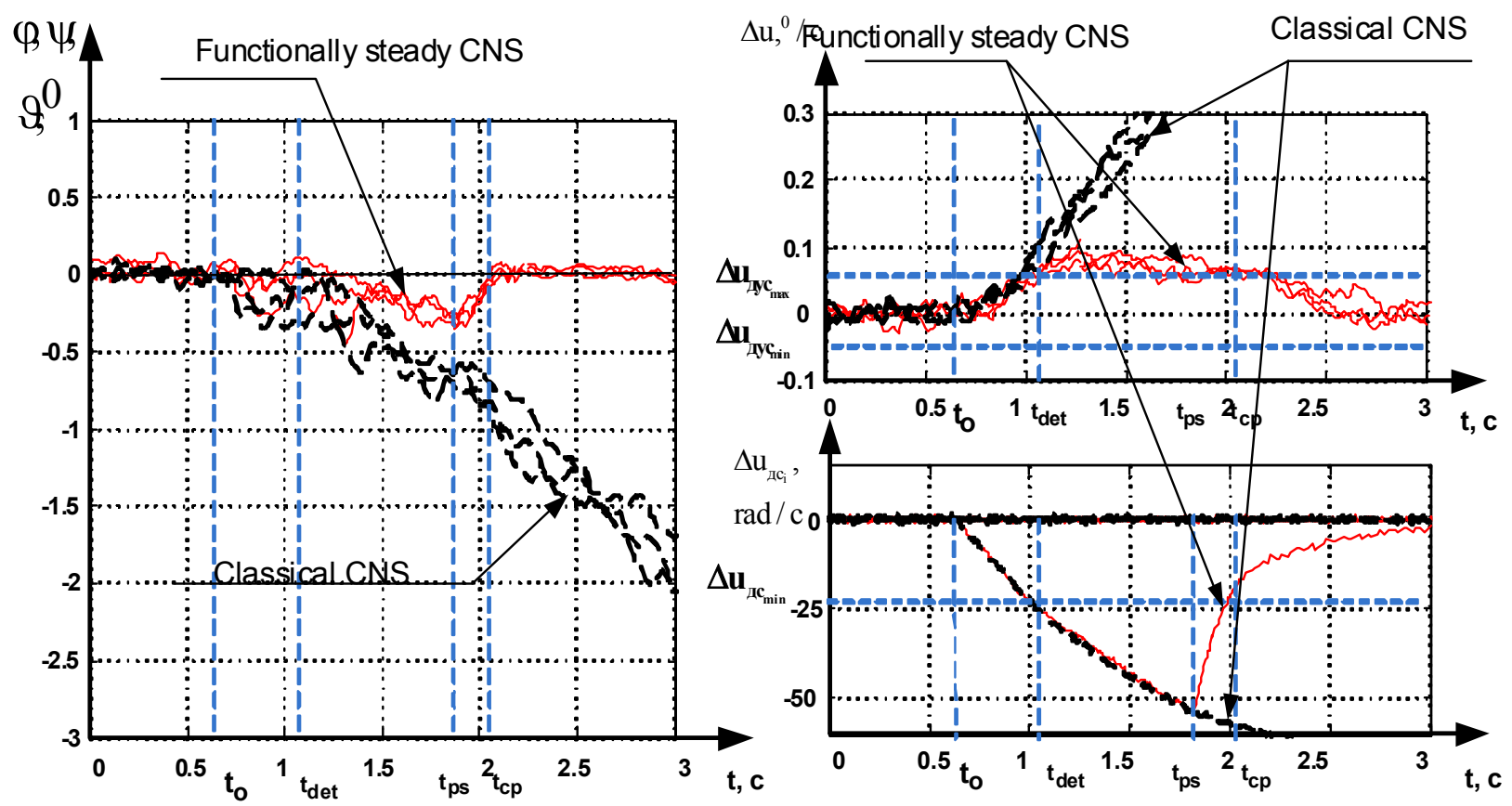

Figure 1 - Results of a research of functionally steady CNS

As can be seen from the presented graphs, the system without a property of functional stability deviates from the predetermined trajectory. In system with functional stability, the system parries failure and moves on the required trajectory after the moment the failure has been detected.

\section{DISCUSSION}

The world practice of CNS exploitation shows their lowefficiency at various abnormal situations arising in the process of application. A significant proportion of accidents happens due to failures in CNS itself. Traditional engineering approach to parrying of abnormal situations doesn't allow to meet a number of modern and perspective requirements. Theoretical research in the field of functional stability develops in the direction of the fragmentary solution of separate aspects of parrying of abnormal situations. For elimination of the specified contradictions, the complex of the combined scientific and technical tasks aimed at multilevel ensuring CNS with functional stability has been solved.

To compare with analogues [9-11] offered by the groups of researchers, the applied approach of situation-dependent parrying is based on the principles of adaptation to CNS specifics and possible abnormal situations and tasks of a mission. Within current approach, parrying of abnormal situations is made after detailed, deep and high-quality diagnosing not only on the base of object's technical condition, but including its functional state.

Thus, the new concept of ensuring functional stability of CNS has been formed. It is based on the principles and results of the modern control theory, applied to the solution of functional stability problem, and on the methods of signal-parametric diagnosing of systems in contrast to common fault-tolerant approaches. With that, for the implementation of the concept application, more advanced models, allowing to design an independent dynamic object with CNS both in nominal and in abnormal operation have been offered. Methods to recover abnormal situations include methods of intelligent analysis on the base tree-like knowledge base and further flexible reconfiguration of the available onboard resources, which was outside the scope of recent results presented by researchers.

\section{CONCLUSIONS}

Analyses of tendencies of theoretical investigation and practical achievements in ensuring functionally steady control of CNS at occurrence of abnormal situations has been carried out. The concept of intelligent support of the functionally steady control of CNS has been developed. The concept is based on the principles of multilevel hierarchical diagnosis of CNS to the parried reason of abnormal situation, as well as on the situational approach to eliminate the consequences of failures in accordance with the level of its application. As a result of analysis and synthesis of known approaches to diagnosing the technical state of dynamic objects, the new models and methods for deep diagnosis of the CNS' functional state have been formed, that makes possible to determine the failure up to the reason of abnormality. Models and methods for multilevel parrying of abnormality through control over the diagnosis with the use of available intelligent on-board resources have been offered. A hardware-software complex for experimental research of theoretical positions have been developed, and conducted experiments have been verified the possibility of extending the functionality of the system to counter abnormal situations. As a result of conducted experiments in real-time scale, diagnosis and restoration of CNS' functional state during a time not exceeding $42.2 \%$ $48.4 \%$ of the transient time of the system in normal operation mode have been implemented.

\section{ACKNOWLEDGEMENTS}

Research is carried out in accordance with the plan of research works within the framework of "Concept of State Policy Implementation in the Sphere of Space Activities on 
the period up to 2031" (approved by the Cabinet of Ministers of Ukraine on 30.03.2011, No. 238-p) and also according to the Agreement on Cooperation with the Aerospace Company «MAVA TECHNOLOGIES», Mexico.

\section{REFERENCES}

1. Gostev V. I. Intermodular exchange of diagnosis information in Selfdiagnosis of complex systems [Text] / V. I. Gostev, O. A. Mashkov, V. A. Mashkov // Cybernetics and Computing Technology, Discrete Control Systems. - 1999. - Vol. 105, № 2. P. 95-103.

2. Gostev V.I. Methods for providing fault tolerance of airborne computer system through their self-control [Text] / V. I. Gostev, O. A. Mashkov, V. A. Mashkov // Cybernetics and Computing Technology, Discrete Control Systems. - 1999. - Vol. 109, № 4 P. 33-44.

3. Mashkov O. Fault-Tolerant of Computing Systems based on the Self-diagnosis by the traveling kerning Principle [Text] / O. Mashkov, V. Mashkov// Cybernetics and Computing Technology, Discrete Control Systems. - 1999. - Vol. 106, №3. - P. 89-94.

4. Gostev V. I. Self-diagnostic of modular systems in random performance of elementary tests [Text] / V. I. Gostev, O. A. Mashkov, V. A. Mashkov // Cybernetics and Computing Technology, Discrete Control Systems. - 1995. - Vol. 99, № 3 P. $104-112$.

5. Firsov S. N. Formation of Fault-Tolerant Flywheel Engine Units in Satellite Stabilization and Attitude Control Systems [Text] / S. N. Firsov // Journal of Computer and Systems Sciences International. - 2014. - Vol. 53, №4. - P. 601 - 609.

6. Firsov S. Hardware and Software Package for Search, Detection and First Aid Means Delivery in Rough Terrain on Basis of a Three Rotor Unmanned Aerial Vehicle [Text] / S. Firsov,

N. Plavynska, K. Rudenko // Transport Problems. - 2014. Vol. 9, Issue 2. - P. 69-75.

7. Машков О. А. Оцінка ефективності застосування функціонально стійких систем дистанційно пілотованих літальних апаратів при моніторингу навколишнього природного середовища в умовах турбулентної атмосфери [Текст] / О. А. Машков, О. М. Щукін // Моделювання та інформаційні технології. 2013. - Вип. 69, №2. - С. 152-158.

8. Кравченко Ю. В. Сучасний стан та шляхи розвитку теорії функціональної стійкості [Текст] / Ю. В. Кравченко, С. А. Мюкіс // Моделювання та інформаційні технології. 2013. - Вип. 68, № 1. - С. 60-68.

9. Castaldi, P. Fault Tolerant Control Schemes for Nonlinear Models of Aircraft and Spacecraft Systems [Text] / P. Castaldi, N. Mimm, S. Simani // 18th IFAC: World Congress, 28.08-02.09 2011. P. $13705-13710$.

10. Huang Jianzhuang. Fault-Tolerant Sensor Placement Based on Control Reconfigurability [Text] / Jianzhuang Huang, N. Eva Wu // 18th IFAC: World Congress, 28.08-02.09 2011 - P. 1481414819.

11. Firsov Sergii Compact vertical take-off and landing aerial vehicle for monitoring tasks in dense urban areas [Text] / Sergii Firsov, Igor Kulik // Transport Problems. - 2015. - Vol. 10, Issue 8. - P. 29- 34.

12. Firsov Sergii. Assessment of functional sustainability of computerintegrated technological systems [Text] / Sergii Firsov, O. A. Pishchukhina // Open information and computer-integrated technologies. - 2016. - Vol. 72, №4. - P. 112-121.

13. Firsov S. N. Hardware-software complex for experimental tests of control processes and diagnostics of small spacecraft's faults [Text] / S. N. Firsov, O. V. Reznikova - Devices and systems. Management, monitoring, diagnostics. - 2014. - Vol. 6. - P. 60-69.

Article was submitted 03.09.2017. After revision 12.11.2017.

Фірсов С. М. ${ }^{1}$, Піщухіна О. О. ${ }^{2}$

'Д-р техн. наук, професор кафедри електротехніки, виконуючий обов'язки декану факультету ракетно-космічної техніки Національного аерокосмічного університету ім. М.Є. Жуковського «ХАI», Харків, Україна

${ }^{2}$ Канд. техн. наук, доцент кафедри інформатики Харківського Національного університету радіоелектроніки, Харків, Україна

ІНТЕЛЕКТУАЛЬНА ПІДТРИМКА БАГАТОРІВНЕВОЇ ФУНКЦІОНАЛЬНОЇ СТІЙКОСТІ СИСТЕМ УПРАВЛІННЯ ТА НАВІГАЦІї

Актуальність. Забезпечення функціонально стійкого управління рухом динамічних об'єктів за наявності нештатних ситуацій $\epsilon$ однією $з$ найбільш перспективних дослідницьких задач в області технічного діагностування та відновлення працездатності систем. Використання методів і алгоритмів інтелектуального управління для вирішення даної науково-технічної проблеми дозволяє значно розширити функціональні можливості і поліпшити показники якості систем управління.

Мета роботи - формування підходу до визначення керуючого впливу, що забезпечує функціональну стійкість систем керування та навігації (СКН) в нештатних ситуаціях.

Метод. Запропоновано концепцію забезпечення функціонально стійкого управління рухом динамічних об’єктів. Систематизовано відомі інструментальні засоби діагностування, на підставі яких розроблені нові моделі і методи глибокого діагностування функціонального стану систем управління рухом і навігації з точністю до причини позаштатної ситуації. Синтезовано моделі і методи багаторівневого парирування причин нештатних ситуацій за допомогою управління за діагнозом такими надмірними засобами, як сигнальне $\mathrm{i}$ параметричне підстроювання, реконфігурація алгоритмів і комутація апаратури.

Результати. Наведено результати вирішення комплексу взаємопов'язаних науково-технічних задач, спрямованих на багаторівневе забезпечення функціональної стійкості систем керування та навігації.

Висновки. Проведено аналіз тенденцій теоретичних досліджень та практичних розробок щодо забезпечення функціонально стійкого управління систем керування та навігації за появи нештатних ситуацій. Розроблено концепцію інтелектуального забезпечення функціонально стійкого управління СКН. Концепція базується на принципах багаторівневого ієрархічного діагностування СКН до причини нештатної ситуації, а також ситуаційному підході усунення наслідків відмов відповідно до рівня його застосування. В результаті аналізу і синтезу відомих підходів до діагностування технічного стану динамічних об'єктів сформовано нові моделі і методи глибокого діагностування функціонального стану СКН, що дозволяють визначити відмову з точністю до причини позаштатної ситуації. Запропоновано моделі та методи, що забезпечують багаторівневе парирування нештатних ситуацій СКН в результаті управління за діагнозом з використанням наявних засобів інтелектуалізації бортового обладнання. Розроблено апаратно-програмний комплекс для експериментального дослідження теоретичних положень, що підтвердило можливість розширення функціональних можливостей системи для парирування нештатних ситуацій. В результаті проведення експериментів у реальному масштабі часу забезпечено діагностування та відновлення функціонального стану СКН за час, що не перевищує $42,2 \%-48,4 \%$ часу перехідного процесу системи в штатному режимі функціонування.

Ключові слова: керування, стабілізація, орієнтація, функціонально-стійке керування рухом, нештатна ситуація, діагностування, парирування причини нештатної ситуації. 
Фирсов С. Н. ${ }^{1}$, Пищухина О. А. ${ }^{2}$

${ }^{1}$ Д-р техн. наук, профессор кафедры электротехники, исполняющий обязанности декана факультета ракетно-космической техники Национального аэрокосмического университета им. Н.Е. Жуковского «ХАИ», Харьков, Украина

${ }^{2}$ Канд. техн. наук, доцент кафедры информатики Харьковского национального университета радиоэлектроники, Харьков, Украина

ИНТЕЛЛЕКТУАЛЬНАЯ ПОДДЕРЖКА МНОГОУРОВНЕВОЙ ФУНКЦИОНАЛЬНОЙ УСТОЙЧИВОСТИ СИСТЕМ УПРАВЛЕНИЯ И НАВИГАЦИИ

Актуальность. Обеспечение функционально устойчивого управления движением динамических объектов при наличии нештатных ситуаций представляет собой одну из наиболее перспективных исследовательских задач в области технического диагностирования и восстановления работоспособности систем. Использование методов и алгоритмов интеллектуального управления для решения данной научно-технической проблемы позволяет значительно расширить функциональные возможности и улучшить показатели качества систем управления.

Цель работы - формирование подхода к определению управляющего воздействия, обеспечивающего функциональную устойчивость систем управления и навигации (СУН) в нештатных ситуациях.

Метод. Предложена концепция обеспечения функционального устойчивого управления движением динамических объектов. Систематизированы известные инструментальные средства диагностирования, на основании которых разработаны новые модели и методы глубокого диагностирования функционального состояния систем управления движением и навигации с точностью до причины нештатной ситуации. Синтезированы модели и методы многоуровневого парирования причин нештатных ситуаций посредством управления по диагнозу такими избыточными средствами, как сигнальная и параметрическая подстройки, а также реконфигурация алгоритмов и коммутация аппаратуры.

Результаты. Приведены результаты решения комплекса взаимосвязанных научно-технических задач, направленных на многоуровневое обеспечение функциональной устойчивости СУН.

Выводы. Проведен анализ тенденций теоретических исследований и практических разработок по обеспечению функционально устойчивого управления систем управления и навигации при появлении нештатных ситуаций. Разработана концепция интеллектуального обеспечения функционально устойчивого управления СУН. Концепция базируется на принципах многоуровневого иерархического диагностирования СУН до парируемой причины нештатных ситуаций, а также ситуационном подходе устранения последствий отказов в соответствии с уровнем его применения. В результате анализа и синтеза известных подходов к диагностированию технического состояния динамических объектов сформированы новые модели и методы глубокого диагностирования функционального состояния СУН, позволяющие определить отказ с точностью до причины нештатной ситуации. Предложены модели и методы, обеспечивающие многоуровневое парирование нештатных ситуаций СУН в результате управления по диагнозу с использованием доступных средств интеллектуализации бортового оборудования. Разработан аппаратно-программный комплекс для экспериментального исследования теоретических положений, что подтвердило возможность расширения функциональных возможностей системы для парирования нештатных ситуаций. В результате проведения экспериментов в реальном масштабе времени обеспечено диагностирование и восстановление функционального состояния СУН за время, не превышающее $42,2 \%-48,4 \%$ времени переходного процесса системы в штатном режиме функционирования.

Ключевые слова: управление, стабилизация, ориентация, функционально устойчивое управление движением, нештатная ситуация, диагностирование, парирование причины нештатной ситуации.

\section{REFERENCES}

1. Gostev V. I., Mashkov O. A., Mashkov V. A. Intermodular exchange of diagnosis information in Selfdiagnosis of complex systems, Cybernetics and Computing Technology, Discrete Control Systems, 1999, Vol. 105, No. 2, pp. 95-103..

2. Gostev V. I., Mashkov O. A., Mashkov V. A. Methods for providing fault tolerance of airborne computer system through their selfcontrol [Text], Cybernetics and Computing Technology, Discrete Control Systems, 1999, Vol. 109, No. 4, pp. 33-44.

3. Mashkov O., Mashkov V. Fault-Tolerant of Computing Systems based on the Self-diagnosis by the traveling kerning Principle, Cybernetics and Computing Technology, Discrete Control Systems, 1999, Vol. 106, No. 3, pp. 89-94.

4. Gostev V. I., Mashkov O. A., Mashkov V. A. Self-diagnostic of modular systems in random performance of elementary tests, Cybernetics and Computing Technology, Discrete Control Systems, 1995, Vol. 99, No. 3, pp. 104-112.

5. Firsov, S. N. Formation of Fault-Tolerant Flywheel Engine Units in Satellite Stabilization and Attitude Control Systems, Journal of Computer and Systems Sciences International, 2014, Vol. 53, No. 4, pp. 601-609.

6. Firsov S., Plavynska N., Rudenko K. Hardware and Software Package for Search, Detection and First Aid Means Delivery in Rough Terrain on Basis of a Three Rotor Unmanned Aerial Vehicle, Transport Problems, 2014, Vol. 9, Issue 2, pp. 69-75.
7. Mashkov O. A., O. M. Shhukin Ocinka efektyvnosti zastosuvannja funkcional'no stijkyh system dystancijno pilotovanyh lital'nyh aparativ pry monitoryngu navkolyshn'ogo pryrodnogo seredovyshha v umovah turbulentnosti atmosfery, Modeljuvannja ta informacijni tehnologii', 2013, - Vol. 69, No. 2, pp. 152-158.

8. Kravchenko Ju.V., Mykus'S. A. Suchasnyj stan ta shljahy rozvytku teorii' funkcional'noi' stijkosti, Modeljuvannja ta informacijni tehnologii', 2013, Vol. 68, Issue 1, pp. 60-68.

9. Castaldi P., Mimm N., Simani S. Fault Tolerant Control Schemes for Nonlinear Models of Aircraft and Spacecraft Systems [Text], 18th IFAC: World Congress, 28.08-02.09 2011, pp. 1370513710.

10. Huang, Jianzhuang, Eva Wu N. Fault-Tolerant Sensor Placement Based on Control Reconfigurability, 18th IFAC: World Congress, 28.08-02.09 2011, pp. 14814-14819.

11. Firsov Sergii, Igor Kulik Compact vertical take-off and landing aerial vehicle for monitoring tasks in dense urban areas, Transport Problems, 2015, Vol. 10, Issue 8, pp. 29-34.

12. Firsov Sergii, Pishchukhina O. A. Assessment of functional sustainability of computer-integrated technological systems [Text], Open information and computer-integrated technologies, 2016, Vol. 72, No. 4, pp. 112-121.

13. Firsov S. N., Reznikova O. V. Hardware-software complex for experimental tests of control processes and diagnostics of small spacecraft's faults, Devices and systems. Management, monitoring, diagnostics, 2014, Vol. 6, pp. 60-69. 